\title{
Laju Pertumbuhan Rumput Laut Kappaphycus alvarezii dengan Metode Penanaman yang Berbeda di Perairan Laut Desa Sepempang Kabupaten Natuna
}

\section{Seaweed Growth Rate Kappaphycus alvarezii with Different Planting Method in the Waters of Natuna Sea Village Sepempang}

\author{
Hardan ${ }^{1}$, Warsidah ${ }^{*}$, Syarif Irwan Nurdiansyah ${ }^{1}$ \\ ${ }^{1}$ Laboratorium Ilmu Kelautan, FMIPA Universitas Tanjungpura, Pontianak, Indonesia \\ *E-mail : warsidah@fmipa.untan.ac.id
}

Received : 10 October 2019; Accepted: 19 November 2019

Published: 27 Febuari 2020 (C) Author(s) 2020. This article is open access

\begin{abstract}
The application of seaweed cultivation methods in Indonesia is very often done by coastal communities. A variety of methods are applied to improve production. This study uses 4 types of cultivation methods: bottom off, floating rafts, long lines and floating net cages. Planting was carried out for \pm 42 days with an initial weight (wet weight) $100 \mathrm{~g}$ and as many as 9 replications in each method. The floating net cage method shows the average growth rate is higher than the long, long line, floating raft, and bottom release with values of $3.232 \%$, $3.139 \%, 2.779 \%$ and $2.424 \%$ respectively.
\end{abstract}

Keywords : Kappaphycus alvarecii, growth rate, cultivation method

\begin{abstract}
Abstrak
Penerapan metode budidaya rumput laut di Indonesia sangat sering dilakukan oleh masyarakat pesisir. Berbagai variasi metode diterapkan untuk meningkatkan hasil produksi. Penelitian ini menggunakan 4 jenis metode budidaya yaitu, metode lepas dasar, rakit apung, rawai panjang dan keramba jaring apung. Penanaman dilakukan selama \pm 42 hari dengan berat awal (berat basah) $100 \mathrm{~g}$ dan sebanyak 9 ulangan pada setiap metode. Metode keramba jaring apung menunjukkan rata-rata laju pertumbuhan lebih tinggi dibandingkan dengan rawai panjang, rakit apung, dan lepas dasar dengan masing-masing adalah nilai $3,232 \%, 3,139 \%, 2,779 \%$ dan $2,424 \%$.
\end{abstract}

Kata kunci : Kappaphycus alvarecii, laju pertumbuhan, metode budidaya

\section{Pendahuluan}

Rumput laut merupakan salah satu sumber daya hayati laut yang bernilai ekonomis dan ekologis. Manfaat ekologis rumput laut yaitu menyediakan habitat untuk beberapa kelompok biota laut seperti jenis Crustasea, Mollusca, ikan dan biota kecil lainnya. Bentuknya yang rimbun mampu memberikan perlindungan terhadap ombak dan juga menjadi makanan bagi biota laut (Wijayanto et al., 2011). Manfaat ekonomis rumput laut yaitu memberikan potensi sebagai salah satu komoditi perikanan Indonesia yang memiliki nilai ekonomis dan mudah dikembangkan melalui akuakultur atau pembudidayaan (Anggadiredja et al., 2010).

Budidaya rumput laut mempunyai peluang sangat baik untuk dikembangkan di wilayah perairan Indonesia. Salah satu jenis rumput laut yang sering dikembangkan adalah jenis Euchema cottoni (Syn. Kappaphycus alvarezii) (Anggadiredja et al., 2010). Rumput laut K. alvarezii memiliki kandungan karagin yang telah banyak dimanfaatkan sebagai

bahan utama industri makanan, kosmetik, farmasi, dan pupuk organik (Aslan, 1998). Budidaya rumput laut yang dilakukan di perairan Indonesia pada umumnya 
menggunakan tiga metode budidaya, yaitu metode lepas dasar (off-bottom method), metode rakit apung (floating raft method), dan metode rawai panjang (long line method) (Anggadiredja et al., 2010).

Menurut Bayu et al. (2011), laju pertumbuhan rumput laut pada metode rawai panjang lebih tinggi dibandingkan metode lepas dasar. Susilowati et al. (2012), mengemukakan bahwa budidaya dengan metode rawai panjang (long line) pada kedalaman yang berbeda memberikan laju pertumbuhan rumput laut di permukaan lebih tinggi dibandingkan di dasar. Mudeng dan Ngangi (2014), mengemukakan bahwa metode rakit apung dapat meningkatkan laju pertumbuhan rumput laut secara optimal jika pemilihan lokasi penanamannya tepat dan terhindar dari pencemaran lingkungan yang dapat menimbulkan penyakit bagi rumput laut. Keberhasilan budi daya rumput laut sangat ditentukan sejak penentuan lokasi (Anggadiredja et al., 2010)

Desa Sepempang merupakan salah satu desa yang terdapat di Kecamatan Bunguran Timur dan memiliki potensi dalam penerapan budidaya rumput laut. Berdasarkan penelitian BP3SP (2008), terhadap analisa spasial kawasan budidaya rumput laut mendapatkan bahwa Desa Sepempang merupakan salah satu dari 9 desa yang ada di Kabupaten Natuna, Kepulauan Riau dengan potensi yang sesuai dalam kelayakan lahan budidaya rumput laut. Kelayakan suatu lahan budidaya akan mampu memberikan dorongan yang baik bagi pertumbuhan rumput laut. Keadaan tersebut dipengaruhi oleh pemilihan metode penanaman yang tepat atau efektif sehingga dapat meningkatkan laju pertumbuhan rumput laut. Penelitian terkait laju pertumbuhan rumput laut $K$. alvarezii di Perairan Laut Desa Sepempang, Kabupaten Natuna perlu dilakukan untuk mengetahui laju pertumbuhan dan metode apa yang paling efektif untuk meningkatkan laju pertumbuhan rumput laut $K$. alvarezii di kawasan tersebut.

\section{Metode}

\subsection{Waktu dan Lokasi Penelitian}

Penelitian ini dilakukan dari tanggal 10 Januari - 20 Februari 2019 selama 6 minggu
( \pm 42 hari) di Perairan Laut Desa Sepempang, Kabupaten Natuna.

\subsection{Tahapan Penanaman}

Penanaman dilakukan dengan 4 metode yaitu rawai panjang (RP), rakit apung (RA), lepas dasar (LD), dan keramba jaring apung (KJA). Setiap metode diikat dengan bibit rumput laut $K$. alvarezii sebanyak 9 kali ulangan dengan berat awal (basah) $100 \mathrm{~g}$. Jarak ikatan bibit $25 \mathrm{~cm}$, jarak dari permukaan untuk RA, RP, dan KJA $30 \mathrm{~cm}$, sedangkan LD 30 $\mathrm{cm}$ dari dasar perairan.

\subsection{Pengambilan dan Penukuran Data}

Pengambilan data faktor lingkungan di lokasi penelitian ini yaitu: salinitas, DO, $\mathrm{pH}$, suhu, kecepatan arus, kedalaman, dan kecerahan air. Pengukuran data laju pertumbuhan dilakukan dengan menimbang pertambahan berat rumput laut $\mathrm{K}$. alvarezii setiap 1 minggu selama 6 minggu ( \pm 42 hari).

\subsection{Analisis Data}

\subsubsection{Laju Pertumbuhan Rumput Laut}

Laju pertumbuhan rumput laut ditentukan pada setiap minggu (sampling) selama 6 minggu ( \pm 42 hari) dengan menggunakan rumus (Ditjenkanbud, 2007) :

$$
G=\left\{\left[\frac{W_{n}}{W_{o}}\right]^{1 / 2}-1\right\} x 100 \%
$$

Keterangan :

G : Laju Pertumbuhan (\% g/hari)

Wn : Bobot Rata-rata Akhir (g)

Wo : Bobot Rata-rata Awal (g)

n : Waktu Pengujian (hari)

\subsubsection{Pertumbuhan Nisbi/Relatif}

Penentuan pertumbuhan nisbi/relatif rumput laut yang diukur pada setiap minggu (sampling) pengamatan selama enam minggu ( \pm 42 hari) dengan rumus umum Menurut Aji (1991).

$$
h=\frac{W_{t} W_{0}}{W_{0}}
$$


Jurnal Laut Khatulistiwa, Vol. 3, No. 1 (Febuari, 2020), Hal. 14-22.

Tabel 1. Hasil perhitungan rata-rata pertumbuhan rumput laut $K$. alvarezii

\begin{tabular}{cccccc}
\hline No & $\begin{array}{c}\text { Jenis } \\
\text { Metode }\end{array}$ & $\begin{array}{c}\text { Pertumbuhan } \\
\text { Mutlak (g) }\end{array}$ & $\begin{array}{c}\text { Pertambahan } \\
\text { Berat } \\
\text { (g/minggu) }\end{array}$ & $\begin{array}{c}\text { Pertumbuhan } \\
\text { Nisbi (g/hari) }\end{array}$ & $\begin{array}{c}\text { Laju } \\
\text { pertumbuhan } \\
\text { (\%) }\end{array}$ \\
\hline 1 & RA & 189,24 & 27,98 & 1,04 & 2,78 \\
2 & RP & 199,7 & 31,13 & 1,37 & 3,14 \\
3 & KJA & 221,6 & 41,19 & 1,42 & 3,23 \\
4 & LD & 185,89 & 31,33 & 1 & 2,42 \\
\hline
\end{tabular}

Keterangan:

h : Pertumbuhan Nisbi/relatif (g)

Wt : Berat setelah thari $(\mathrm{g})$

Wo : Berat awal (g)

\subsubsection{Analisis statistik pertumbuhan rumput laut $K$. alvarezii}

Data pertumbuhan rumput laut $K$. alvarezii diuji dengan menggunakan analisis ragam atau Analysis of Varians. Uji statistik dilakukan dengan menggunakan software Statistical Package for the Social Sciences (SPSS) v. 24 (Bayu et al., 2011).

\section{Hasil dan Pembahasan}

\subsection{Pertumbuhan Rumput Laut}

Pertumbuhan rumput laut diamati berdasarkan pertambahan beratnya yang dilakukan dengan penimbangan pada setiap 1 minggu selama 6 minggu penanaman $( \pm 42$ hari). Angka hasil penimbangan, selanjutnya digunakan untuk menentukan pertumbuhan mutlak, pertambahan berat, pertumbuhan nisbi/relatif dan laju pertumbuhan rumput laut. Hasil perhitungan tersebut disajikan pada Tabel 1.

\subsection{Pertumbuhan mutlak pertambahan berat}

dan

Pertumbuhan mutlak (Gambar 1) dan pertambahan berat (Gambar 2) rumput laut K. alvarezii yang dihasilkan selama 6 minggu penanaman dari 4 metode yang diterapkan menunjukkan metode KJA memiliki nilai ratarata lebih tinggi dibandingkan metode lainnya. Gambar 1 dan 2 menunjukkan bahwa metode KJA memiliki nilai pertumbuhan mutlak lebih dan pertambahan berat lebih tinggi dibandingkan metode lainnya.

Beberapa faktor yang diduga berpengaruh terhadap nilai tersebut yaitu, metode KJA terlindung dari sampah dan predator yang dapat menghambat pertumbuhan rumput laut, sehingga pada metode KJA nilai pertumbuhannya lebih baik dibandingkan metode lainnya. Sunyoto (1994) menyebutkan bahwa metode KJA memiliki beberapa keuntungan yaitu predator mudah dikendalikan, mudah dipanen, jumlah dan mutu air selalu memadai. Predator juga menjadi kendala yang sangat berpengaruh terhadap laju pertumbuhan rumput laut. Semakin banyak predator cenderung mengakibatkan kerusakan dan terhambatnya pertumbuhan rumput laut.

Hama rumput laut $K$. alvarezii merupakan organisme laut, terutama ikan baronang dan penyu. Hama tersebut menyebabkan kerusakan fisik pada tanaman budidaya, seperti terkelupas, patah, atau habis dimakan (Sudradjat, 2009). Kerusakan rumput laut dapat disebabkan oleh gelombang besar dan dimakan oleh herbivora, seperti ikan baronang dan penyu. Untuk menghindari predator tersebut dapat dilakukan dengan memagari sekeliling blok rumput laut dengan jaring (Anggadiredja et al., 2010). Berdasarkan pernyataan tersebut, dapat dikatakan bahwa metode KJA merupakan solusi dari permasalahan terhadap predator. Ukuran jaring juga dapat dikendalikan sesuai dengan kebutuhan atau sesuai dengan pertimbangan ukuran predator yang ada disekitar lokasi budidaya.

Hasil penelitian menunjukkan adanya perbedaan antara rimbun yang dihasilkan metode RA, RP, dan LD dibandingkan metode KJA. Pada metode KJA rimbun rumput laut 
Jurnal Laut Khatulistiwa, Vol. 3, No. 1 (Febuari, 2020), Hal. 14-22.

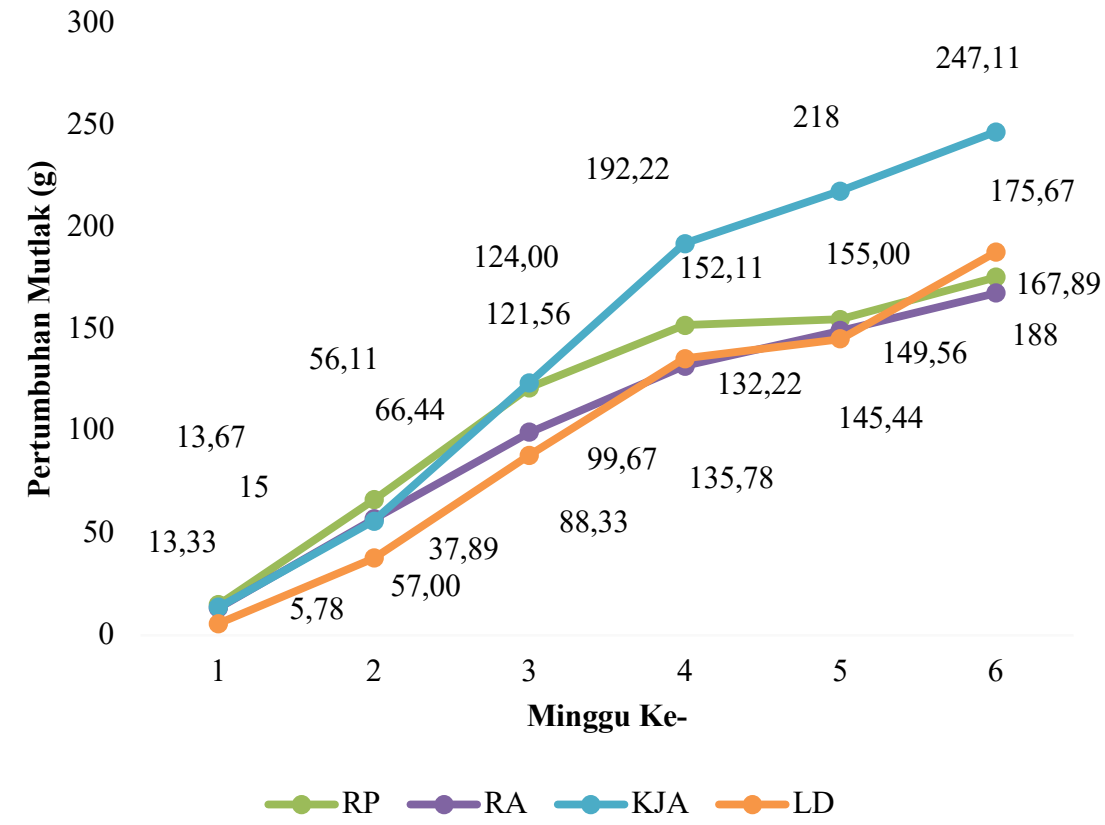

Gambar 1. Grafik pertumbuhan mutlak rumput laut $K$. alvareziii di perairan Laut Desa Sepempang Kabupaten Natuna

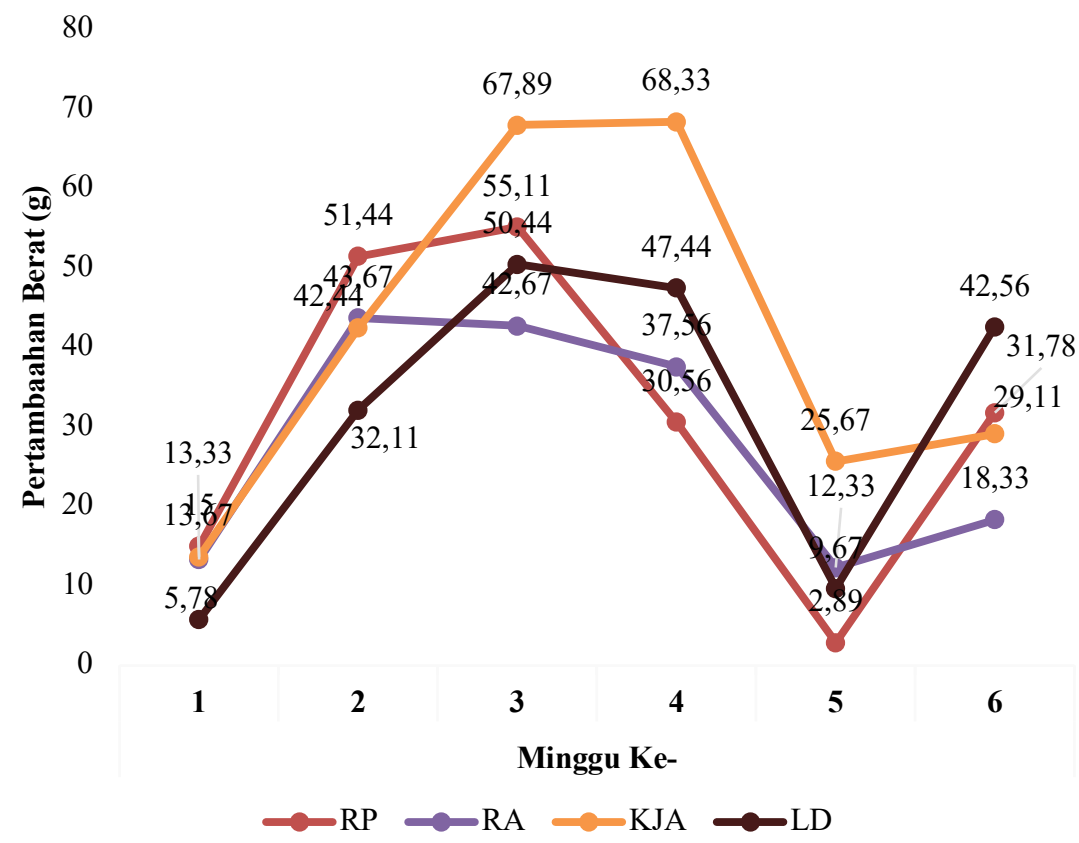

Gambar 2. Grafik pertambahan berat rumput laut K. alvarezii selama 6 minggu penanaman di Perairairan Laut Desa Sepempang Kabupaten Natuna

terlihat hijau dan tebal serta tidak adanya bercak-bercak terkelupas dan terputus. Sedangkan 3 metode lainnya memiliki rimbun lebih kecil yang diduga dimakan oleh predator dan terlihat bercak terkelupas dan beberapa bagian thallus terputus (Gambar 3).

\subsection{Pertumbuhan Rhizopora apiculata}

Laju pertumbuhan nisbi/relatif pada penanaman rumput laut $K$. alvarezii selama 6 minggu ( \pm 42 hari) (Gambar 4.) menunjukkan nilai laju pertumbuhan dengan metode KJA lebih tinggi dibandingkan metode lainnya, 


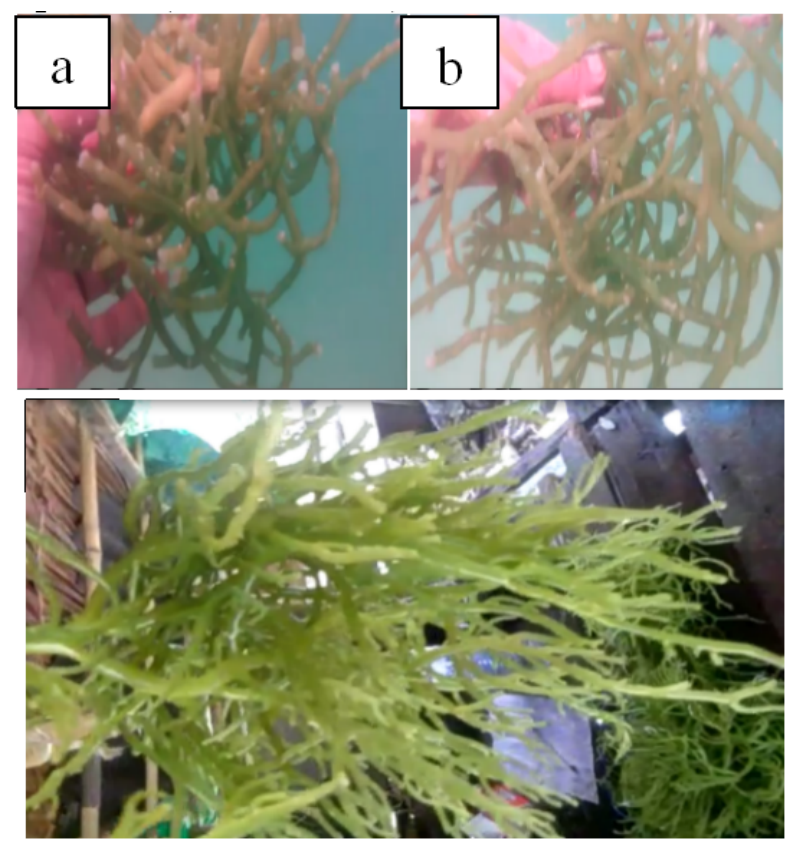

Gambar 3. Thallus tampak putus dan terkelupas LD (a) dan RP (b), rimbun subur dan thallus runcing KJA (c)

yaitu $1,42 \mathrm{~g} / \mathrm{hari}$, sedangkan nilai terendah ditunjukkan oleh metode LD dengan nilai 1,01 $\mathrm{g} /$ hari. Metode RA dan RP memiliki nilai laju pertumbuhan nisbi/relatif masing-masing 1,38 g/hari dan 1,04 g/hari. Nilai ini menunjukkan bahwa pada metode KJA memiliki nilai pertumbahan berat nisbi/relatif lebih tinggi dibandingkan metode lainnya.

Laju pertumbuhan harian rumput laut $\mathrm{K}$. alvarezii selama 6 minggu periode penanaman (Gambar 5) menunjukkan nilai laju pertumbuhan dengan metode KJA lebih 3,232 $\%$, sedangkan laju pertumbuhan yang paling lambat terjadi pada metode LD dengan nilai 2,424\%. Anggadiredja et al., (2008) menyebutkan bahwa pertumbuhan yang baik jika nilai persentase laju pertumbuhannya melebihi dari 3\%. Dari ke 4 metode yang digunakan menunjukkan bahwa 2 metode yaitu KJA dan RP memiliki nilai $>3 \%$, sehingga dikatakan pada 2 metode tersebut memiliki pertumbuhan rumput yang baik dibandingkan metode RA dan LD

\subsection{Parameter Lingkungan}

Pertumbuhan rumput laut $K$. alvarezii sangat dipengaruhi oleh faktor kualitas lingkungan. Faktor kualitas lingkungan yang diukur di lokasi penelitian ini di antaranya, yaitu: salinitas, suhu, $\mathrm{pH}$, oksigen terlarut, kedalaman, kecerahan dan kecepatan arus. Hasil pengukuran dari setiap faktor kualitas perairan menunjukkan bahwa masing-masing faktor termasuk kedalam batas optimal bagi pertumbuhan rumput laut.

Menurut Sudradjat (2009) K. alvarezii merupakan rumput laut yang tidak tahan terhadap kisaran salinitas tinggi (stenohaline), dan salinitas yang sesuai untuk pertumbuhannya berada pada kisaran 28-35 ppt. Sedangkan menurut Anggadiredja et al., (2010) K. alvarezii tumbuh baik pada kisaran 28-33 ppt. Pengukuran salinitas di wilayah budidaya pada penelitian ini selama 6 minggu penanaman memiliki nilai rata-rata 32,74 ppt. Angka tersebut menunjukkan bahwa salinitas pada lokasi penanaman berada dalam kisaran optimal bagi pertumbuhan rumput laut $K$. alvarezii.

Penelitian Bayu et al., (2011) memperoleh data pengukuran terhadap salinitas di lokasi penelitiannya dengan nilai $30 \mathrm{ppt}$ dan masih berada dalam kisaran optimal bagi pertumbuhan rumput laut, sehingga laju pertumbuhan rumput laut pada kedua metode RA dan LD yang diterapkan mampu tumbuh dengan baik yang ditandai dengan laju pertumbuhan hariannya mencapai $5 \%$. Mudeng dan Ngangi (2014) juga memperoleh nilai salintas pada penelitian pola tanam rumput laut $K$. alvarezii di Pulau Nain 


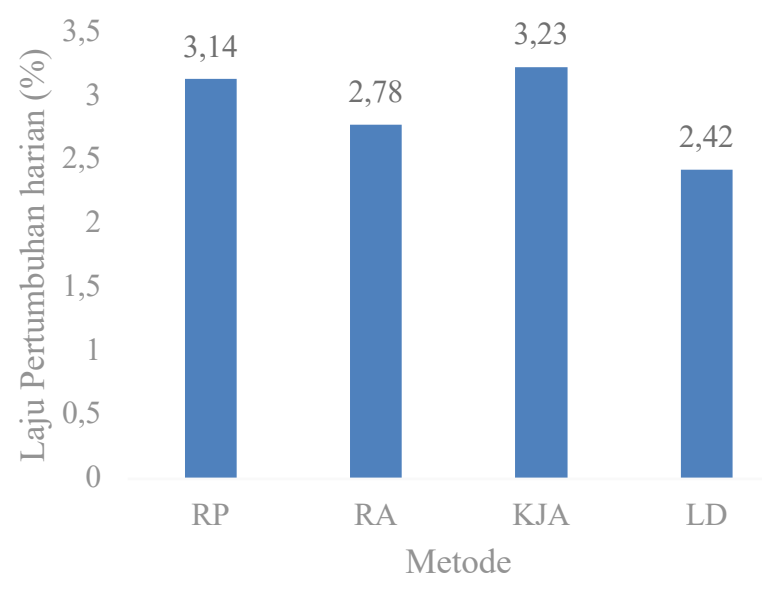

Gambar 5. Grafik pertumbuhan nisbi/relatif rumput laut K. alvarezii

Kabupaten Minahasa Utara dengan kisaran 3034 ppt.

Suhu yang terlalu tinggi atau terlalu rendah dapat mempengaruhi laju pertumbuhan rumput laut dan bahkan dapat menyebabkan kematian rumput laut. Suhu rata-rata yang diperoleh pada pengukuran di lokasi budidaya selama 6 minggu penanaman yaitu $30^{\circ}$ C. Menurut Anggadiredja et. al., (2010), suhu optimal pertumbuhan rumput laut $K$. alvarezii berada pada kisaran 26-30 oC. Hal ini menunjukkan bahwa pada lokasi penanaman memiliki suhu yang optimal bagi pertumbuhan rumput laut.

Kadar $\mathrm{pH}$ atau keasaman air laut juga memiliki pengaruh yang sangat besar bagi pertumbuhan rumput laut. Menurut Sudradjat (2009), kadar keasaman air laut yang baik bagi pertumbuhan $K$. alvarezii berada pada kisaran 7,3-8,2. Sedangkan menurut Sadhori (1989) kisaran optimal pH yang baik bagi pertumbuhan $K$. alvarezii berada pada kisaran 6,8-9,6. Pengukuran $\mathrm{pH}$ rata-rata yang diperoleh pada lokasi penanaman rumput laut K. alvarezii selama 6 minggu memiliki nilai 7,9. Angka tersebut menunjukkan bahwa nilai $\mathrm{pH}$ pada lokasi penanaman berada pada kisaran optimal bagi pertumbuhan rumput laut $K$. alvarezii.

Organisme perairan selalu tergantung pada ketersediaan oksigen yang terlarut dalam perairan tersebut. Rumput laut $K$. alvarezii mampu hidup pada kondisi DO 4-6 mg/l dan optimal jika DO >6 mg/l (Dahuri, 1996). Pengukuran DO pada lokasi penelitian memperoleh hasil rata-rata $17,65 \mathrm{mg} / \mathrm{l}$. Nilai tersebut menunjukkan bahwa lokasi penelitian memiliki DO yang lebih dari batas optimum untuk pertumbuhan rumput laut $K$. alvarezii. Novyandi et al. (2011) melakukan penelitian terkait penanaman rumput laut Gracilaria sp. dengan metode rak bertingkat di Perairan Kalianda, Lampung Selatan mendapatkan nilai D0 6,4 mg/l. Nilai tersebut memberikan laju pertumbuhan yang baik bagi rumput laut laut yang ditandai dengan laju pertumbuhan melibihi 3\% yaitu 4,26\%.

Kedalaman perairan juga dapat mempengaruhi pertumbuhan rumput laut. Budidaya rumput laut harus memiliki kedalaman minimal $0,40 \mathrm{~m}$ pada saat surut terendah (Anggadiredja et al., 2010). Pada penelitian ini, kedalaman yang diperoleh selama pengukuran ( 6 minggu) memiliki nilai rata-rata 148,08 cm. Sedangkan untuk kedalaman terendah diperoleh pada minggu pertama dengan kedalaman $60 \mathrm{~cm}$ dan kedalaman tertinggi diperoleh pada minggu ke 3 dengan kedalaman $240 \mathrm{~cm}$. Berdasarkan hasil tersebut, dapat dikatakan bahwa lokasi penelitian memiliki kedalaman di atas batas kedalaman minimal dan sesuai untuk diterapkan pada budidaya rumput laut. Kedalaman suatu perairan sangat berkaitan dengan tingkat kecerahan air dimana masih terdapat cahaya mata hari yang masuk dalam perairan tersebut.

Kecerahan air dapat memberikan pengaruh terhadap laju pertumbuhan rumput laut. Tingkat kecerahan air yang sesuai untuk 
Jurnal Laut Khatulistiwa, Vol. 3, No. 1 (Febuari, 2020), Hal. 14-22.

Tabel 2. Hasil pengukuran faktor kualitas lingkungan di lokasi budidaya

\begin{tabular}{|c|c|c|c|}
\hline No & Parameter & Rerata Nilai Pengukuran & Kisaran Optimal \\
\hline 1 & Salinitas & $32,74 \mathrm{ppt}$ & $\begin{array}{l}\text { 28-34 ppt } \\
\text { (Tiensongrusmee,1990), } \\
\text { 28-35 ppt (Sudradjat, 2009), 28- } \\
33 \text { ppt (Anggadiredja } \text { et al., 2010) }\end{array}$ \\
\hline 2 & Suhu & $30,44^{\circ} \mathrm{C}$ & $\begin{array}{l}\text { 20-28 }{ }^{\circ} \mathrm{C} \text { (Sudradjat, 2009), 20- } \\
30{ }^{\circ} \mathrm{C} \text { (Setiyanto et al., 2008) 26- } \\
30{ }^{\circ} \mathrm{C} \text { (Anggadiredja et al., } \\
\text { 2010), 20-28 }{ }^{\circ} \mathrm{C} \text { (Parenrengi et } \\
\text { al., 2010). }\end{array}$ \\
\hline 3 & $\mathrm{pH}$ & 7,91 & $\begin{array}{l}\text { 6,8-9 (Sadhori, 1989), 7,3- 8,2 } \\
\text { (Sudradjat, 2009), 5- }\end{array}$ \\
\hline 4 & Oksigen Terlarut & $17,65 \mathrm{mg} / \mathrm{L}$ & $>6$ (Dahuri, 1996) \\
\hline 5 & Kedalaman & $148,08 \mathrm{~cm}$ & $\begin{array}{l}60-200 \mathrm{~cm} \text { (Anggadiredja et al., } \\
2010)\end{array}$ \\
\hline 6 & Kecerahan & $100 \%$ dari total kedalaman air. & 2-5 m (Anggadiredja et al., 2010) \\
\hline 7 & Kecepatan arus & $0,4 \mathrm{~m} / \mathrm{s}$ & $\begin{array}{l}0,2-0,4 \mathrm{~m} / \mathrm{s} \text { (Indriani dan } \\
\text { Sumiarsih, 2003), 0,2-0,4 m/s } \\
\text { (Anggadiredja et al., 2010), 0,2- } \\
0,4 \mathrm{~m} / \mathrm{s} \text { (Sudradjat, 2009) }\end{array}$ \\
\hline
\end{tabular}

Tabel 3. Hasil pengukuran faktor kualitas lingkungan di lokasi budidaya

\begin{tabular}{ccccc}
\hline Metode & N & Mean & Std. Deviation & Std. Error \\
\hline RP & 6 & 216.14783 & 64.065454 & 26.154612 \\
RA & 6 & 204.11067 & 59.512773 & 24.295988 \\
KJA & 6 & 241.87017 & 93.303985 & 38.091192 \\
LD & 6 & 200.20317 & 69.225568 & 28.261220 \\
\hline
\end{tabular}

budidaya rumput laut dan memberikan pertumbuhan yang baik terhadap rumput laut harus mencapai 2-5 m (Aggadiredja et al., 2010 dan Sudradjat, 2009). Hasil pengukuran dengan menggunakan secchi disk memperoleh nilai bahwa tingkat kecerahannya sama dengan kedalaman total air laut atau dikatakan $100 \%$, artinya baik kedalaman terendah $60 \mathrm{~cm}$ sampai kedalaman tertinggi $240 \mathrm{~cm}$ secchi disk tetap terlihat dengan jelas (Gambar 4.8). Penelitian Haryasakti (2017), memperoleh pengukuran terhadap kedalaman dan kecerahan memiliki nilai yang sama. Pada kedalaman $4 \mathrm{~m}$, kecerahan yang diperoleh juga $4 \mathrm{~m}$ dan pada kedalaman $2 \mathrm{~m}$ kecerahan juga $2 \mathrm{~m}$.

Kecepatan arus juga menjadi faktor yang dapat mempengaruhi laju pertumbuhan rumput laut K. alvarezii karena rumput laut merupakan tanaman yang memperoleh makanan (unsur hara) melalui aliran air yang melewatinya (Sudradjat, 2009). Namun demikian, rumput laut juga tidak bisa bertahan dengan kecepatan arus kuat. Sesuai dengan Anggadiredja et al., (2010) menyebutkan bahwa lokasi budidaya rumput laut harus berada pada lokasi yang terlindung dari gelombang dan arus yang kuat. Kecepatan arus yang baik untuk penerapan budidaya rumput laut berkisar antara 0,2-0,4 m/detik (Anggadiredja et al., 2010 dan Sudradjat, 2009). Penelitian ini memperoleh kecepatan arus pada lokasi budidaya dengan kisaran 0,4 $\mathrm{m} / \mathrm{s}$. Berdasarkan hasil pengukuran tersebut, dari faktor kecepatan arus menunjukkan bahwa lokasi tersebut cukup baik dalam penerapan budidaya rumput laut, karena berada pada kisaran optimal kecepatan arus 
yang diperlukan oleh rumput laut untuk tumbuh dan memperoleh makan.

Indriani dan Sumiarsih, (2003) juga menyebutkan bahwa rumput laut akan tumbuh dengan baik pada kecepatan arus 20$40 \mathrm{~cm} / \mathrm{dtk}$. Penelitian Bayu et al., (2011) dan Novyandi et al., (2011) memperoleh pengukuran arus $23 \mathrm{~cm} / \mathrm{dtk}$ pada lokasi peneletiannya yang terkait dengan laju pertumbuhan rumput laut Gracilaria sp. di Perairan Kalianda, Lampung Selatan. Dari data yang diperoleh pada penelitian tersebut menunjukkan bahwa laju pertumbuhan rumput laut pada metode LD dan RA serta pada metode rak bertingkat memiliki laju pertumbuhan yang berbeda. Rumput laut pada metode yang dekat dengan permukaan menunjukkan nilai laju pertumbuhan lebih tinggi dibandingkan dengan metode dekat dasar. Hal tersebut diduga karena adanya perbedaan arus dipermukaan dengan dasar, yang ditandai dengan adanya endapan lumpur yang menempel pada thallus rumput laut. Mamang (2008), menyebutkan bahwa pergerakan arus yang baik dapat menghindarkan akumulasi silt dan organisme epifit yang menempel pada thallus yang dapat menghalangi pertumbuhan rumput laut. Hasil pengukuran faktor kualitas lingkungan disajikan dalam Tabel 2.

\subsection{Analisis statistik pertambahan berat rumput laut $K$. alvarezi}

Data pertambahan berat rumput laut $K$. alvarezii selanjutnya dianalisis dengan menggunakan analisis ragam (ANOVA) menggunakan sofware SPSS. Hasil yang diperoleh ditunjukkan pada Tabel 3. Tabel 3. menunjukkan bahwa metode KJA memiliki pertambahan berat paling tinggi dengan nilai rata-rata $241,87 \mathrm{~g}$ dan metode LD memiliki pertambahan berat paling rendah dengan nilai rata-rata $200,20 \mathrm{~g}$.

\section{Kesimpulan}

Berdasarkan hasil yang diperoleh pada penelitian ini dapat disimpulkan bahwa metode KJA memiliki laju pertumbuhan harian lebih tinggi dibandingkan metode RP, RA, dan LD dengan nilai masing-masing yaitu $3,23 \%$, $3,14 \%, 2,78 \%$ dan $2,42 \%$.

\section{Ucapan Terima Kasih}

Ucapan terimakasih kepada seluruh pihak yang terlibat dalam penelitian ini terutama Tuhan Yang Maha Esa, dosen, pemerintah, keluarga, dan teman-teman seperjuangan, serta kepada Kementrian Riset, Teknologi dan Pendidikan Tinggi Indonesia atas program beasiswa Bidikmisi yang telah mendanai penelitian ini.

\section{Daftar Pustaka}

Aji, N. 1991. Budidaya Rumput Laut. Lampung. Direktorat Jenderal Perikanan. Balai Budidaya Laut.

Anggadiredja, J.T., A. Zatnika, H. Purwoto, dan S. Istini. 2010. Rumput Laut: Pembudidayaan, Pengolahan, dan Pemasaran Komoditas Perikanan Potensial. Jakarta: Penebar Swadaya.

Aslan, L.M. 1998. Seri Budidaya Rumput Laut. Yogyakarta: Kanisius.

Bayu, D.P., A. Riris, dan Isnaini. 2011. Laju Pertumbuhan Rumput Laut Gracilaria sp. dengan Metode Penanaman yang Berbeda di Perairan Kalianda, Lampung Selatan. Jurnal Maspari. 3:36-41.

Dahuri, R., J. Rais, S.P. Ginting, dan M.J. Sitepu. 1996. Pengelolaan Sumberdaya Pesisir dan Lautan Secara Terpadu. Jakrta: PT. Pradnya Paramita.

Mamang, N. 2008. Laju Pertumbuhan Bibit Rumput Laut Eucheuma cottonii Dengan Perlakuan Asal Thallus Terhadap Bobot Bibit di Perairan Lakeba, Kota Bau-Bau, Sulawesi Tenggara. Skripsi. Bogor: Institut Teknologi Bogor.

Mudeng, J.D., dan E.L.A Ngangi. 2014. Pola Tanam Rumput Laut Kappaphycus alvarezii di Pulau Nain, Kabupaten Minahasa Utara. Jurnal Budidaya Perairan. 2:27-37.

Novyandi, R., A. Riris, dan Isnaini. 2011. Laju Pertumbuhan Rumput Laut Gracilaria sp dengan Metode Rak Bertingkat di Perairan kalianda, Lampung Selatan. Jurnal Maspari. 3:58-62. 
Jurnal Laut Khatulistiwa, Vol. 3, No. 1 (Febuari, 2020), Hal. 14-22.

Sadhori, S.N. 1989. Budidaya Rumput Laut. Yogyakarta: Balai Pustaka.

Sudradjat, A. 2009. Budidaya 23 Komoditas Laut Menguntungkan. Yogyakarta: Penebar Swadaya.

Sunyoto, P. 1994. Pembesaran Kerapu dengan Keramba Jaring Apung. Jakarta: Penebar Swadaya.

Susilowati, T., R. Sri, N.D. Eko, dan Zulfitriani. 2012. Pengaruh Kedalaman Terhadap Pertumbuhan Rumput Laut (Euchema Cottonii) Yang Dibudidayakan dengan Metode Longline Di Pantai Mlonggo, Kabupaten Jepara. Jurnal Saintek Perikanan. 8:1.

Wijayanto, T., H. Muhammad, dan A. Riris. 2011. Studi Pertumbuhan Rumput Laut Eucheuma cottonii dengan Berbagai Metode Penanaman yang berbeda di Perairan Kalianda, Lampung Selatan. Journal Maspari. 3:51-57. 